\title{
PENGARUH PENERAPAN KURIKULUM 2013 TERHADAP PEMBENTUKAN KARAKTER SISWA KELAS VII H SMP DWIJENDRA TAHUN PELAJARAN 2018/2019
}

\author{
I Made Sutika \\ Program Studi Pendidikan Pancasila dan Kewarganegaraan - FKIP Universitas Dwijendra Denpasar \\ sutika@undwi.ac.id \\ I Nengah Sudiartha \\ Program Studi Pendidikan Pancasila dan Kewarganegaraan - FKIP Universitas Dwijendra Denpasar \\ sudiartha@undwi.ac.id \\ Adrianus Djaiwu Marawali \\ Program Studi Pendidikan Pancasila dan Kewarganegaraan - FKIP Universitas Dwijendra Denpasar \\ adrianus@gmail.com
}

\begin{abstract}
Abstrak
Dimensi pertama memandang kurikulum sebagai rencana kegiatan belajar bagi siswa disekolah atau sebagai perangkat tujuan yang ingin dicapai. Suatu kurikulum dapat menunjuk pada suatu dokumen yang berisi rumusan tentang tujuan, bahan ajar, kegiatan belajar mengajar, jadwal, dan evaluasi. Dimensi kedua, memandang kurikulum suatu sistem yang mencakup struktur personalia dan prosedur kerja bagaimana cara menyusun kurikulum, melaksanakan, mengevaluasi, dan menyempurnakan. Dimensi yang ketiga memandang kurikulum sebagai bidang studi, yaitu bidang studi kurikulum. Namun, dalam kurikulum 2013 ini lebih bertumpu kepada kualitas guru sebagai implementator di lapangan. Adapun rumusan masalah yaitu: 1) Bagaiaman pengaruh penerapan kurikulum 2013 berpengaruh terhadap pembentukan karakter siswa Kelas VII H SMP Dwijendra Denpasar tahun pelajaran 2018/2019? Penelitian ini bertujuan untuk mengetahui pengaruh penerapan Kurikulum 2013 terhadap pembentukan karakter siswa kelas VII H SMP Dwijendra Denpasar tahun pelajaran 2018/2019. Teknik pengumpulan data meliputi wawancara, observasi, dokumentasi. Instrumen penelitian meliputi lembaran angket dan pedoman wawancara. Teknik analisis data meliputi pengumpulan data, reduksi data, penyajian data dan penarikan kesimpulan. Hasil dari penelitian ini menunjukan bahwa penerapan kurikulum 2013 terhadap pembentukan karakter siswa sangat penting. Untuk meningkatkan kualitas kerakter siswa di sekolah guru-guru dapat memberikan keteladanan kepada siswa, memberikan motivasi dan bimbingan yang baik kepada siswa sehingga siswa termotivasi untuk berkarakter dan penyampaian materi yang behubungan dengan kedisiplinan contohnya materi tentang norma-norma. Pemberian hukuman kepada siswa yang melanggar diusahakan selalu bersifat membangun dan mendidik. Perlakuan itu merupakan solusi yang bijak dalam mendisiplinkan siswa di sekolah. Penerapan kurikulum 2013 terhadap pembentukan karakter siswa yaitu sikap yang ada pada diri siswa sendiri, lingkungan dan pola penenaman disiplin dalam keluarga. upaya yang dilakukan guru-guru dalam mengatasi pengaruh tersebut yakni membangun kerjasama dengan orang tua, pihak sekolah dalam.
\end{abstract}

Kata kunci: Penerapan Kurikulum 2013, Pembentukan Karakter Siswa

\begin{abstract}
The first dimension views the curriculum as a plan of learning activities for students at school or as a set of goals to be achieved. A curriculum can refer to a document that contains the formulation of objectives, teaching materials, teaching and learning activities, schedules, and evaluations. The second dimension, looking at the curriculum of a system that includes the personnel structure and work procedures on how to structure the curriculum, implement, evaluate, and improve. The third dimension views the curriculum as a field of study, namely the field of curriculum studies. However, in the 2013 curriculum it is more reliant on the quality of teachers as implementers in the field. The formulation of the problem are: 1) How does the influence of the implementation of the 2013 curriculum affect the character formation of Class VII H students of SMP Dwijendra Denpasar in the academic year 2018/2019? This study aims to determine the effect of the
\end{abstract}


implementation of the 2013 Curriculum on the character building of VII H class students at Dwijendra Denpasar Middle School in 2018/2019. Data collection techniques include interviews, observation, documentation. Research instruments include questionnaire sheets and interview guidelines. Data analysis techniques include data collection, data reduction, data presentation and drawing conclusions. The results of this study indicate that the application of the 2013 curriculum to the formation of student character is very important. To improve the quality of students' characteristics in schools teachers can provide role models to students, provide motivation and good guidance to students so students are motivated to character and delivery of material related to discipline, for example material about norms. Penalties to students who violate the endeavor are always constructive and educational. The treatment is a wise solution in disciplining students at school. The application of the 2013 curriculum to the formation of student character is the attitude that exists in students themselves, the environment and the pattern of discipline in the family. the efforts made by the teachers in overcoming this influence are building cooperation with parents, the inner school.

Keywords: Implementation of 2013 Curriculum, Formation of Student Character

\section{PENDAhuluan}

Seiring berjalannya waktu, kurikulum di Indonesia mengalami perubahan perubahan. Dalam hal ini sekolah dalam pelaksana pendidikan sangat berkepentingan dan tentu saja menjadi lahan utama yang akan terkena imbasnya. Dan semua pihak, baik orang tua, masyarakat, dan semua jajarannya birokrasi juga mendapatkan dampak langsung dari perubahan-perubahan kurikulum itu. Oleh karena itu kurikulum ini harus disikapi secara positif dengan mengkaji dan memahami penerapannya di sekolah. Baru beberapa tahun belakangan ini Indonesia menerapkan Kurikulum 2013 pada sekolah-sekolah baik tingkat dasar maupun tingkat atas. Banyak alasan mengapa terjadi perbahan kurikulum, disamping alasan kurikulum sebelumnya harus disempurnakan karena ada kekurangan disana-sini, serta perubahan kurikulum yang dilakukan oleh pemerintah adalah dengan niatan untuk perbaikan sistem pendidikan, tetapi yang paling mendasar adalah agar kurikulum yang akan diterapkan tersebut mampu menjawab tentang zaman yang terus berubah tanpa dapat dicegah, dan untuk mempersiapkan peserta didik yang mampu bersaing dimasa depan dengan segala kemajuan ilmu pengetahuan dan teknologi.

Dimensi pertama memandang kurikulum sebagai rencana kegiatan belajar bagi siswa disekolah atau sebagai perangkat tujuan yang ingin dicapai. Suatu kurikulum dapat menunjuk pada suatu dokumen yang berisi rumusan tentang tujuan, bhan ajar, kegiatan belajar mengajar, jadwal, dan evaluasi. Dimensi kedua, memandang kurikulum suatu sistem yang mencakup struktur personalia dan prosedur kerja bagaimana cara menyusun kurikulum, melaksanakan, mengevaluasi, dan menyempurnakan. Dimensi yang ketiga memandang kurikulum sebagai bidang studi, yaitu bidang studi kurikulum. Namun, dalam kurikulum 2013 ini lebih bertumpu kepada kualitas guru sebagai implementator di lapangan. Sebagai sistem konsep ini dapat dipastikan mengalami perubahan dari konsep kurikulum yang sebelumnya, sebab wacana pergantian kurikulum dalam sistem pendidikan memang merupakan hal yang wajar, mengingat perkembangan alam manusia terus mengalami perubahan. 
Adapun kelebihan dalam kurikulum 2013 adalah siswa lebih dituntut lebih aktif, kreatif, dan inovatif dalam setiap pemecahan masalah yang mereka hadapi hanya didapat dari nilai ujian saja tetapi juga didapat dari nilai kesopanan, religi, praktek, sikap, dan lain-lain); munculnya pendidikan karakter dan pendidikan budi pekerti yang telah diintegrasikan kedalam semua program studi; adanya kompetensi yang sesuai dengan tuntutan fungsi dan tujuan pendidikan nasional; kompetensi yang dimaksud menggambarkan secara holistik domain sikap, keterampilan, dan pengetahuan; standar penilaian mengarahkan pada penilaian berbasis kompetensi seperti sikap, keterampilan, dan pengetahan secara proporsional; dan lain-lain. Di dalam salah satu kelebihan Kurikulum 2013 telah disebutkan bahwa dalam implementasi Kurikulum 2013 ini menuntut siswa untuk menjadi aktif dan kreatif. Serta dalam penilaian pembelajarannya nilai praktik pun tercantum dalam penilaian Kurikulum 2013. Pendidikan mempunyai peranan yang sangat menentukan bagi perkembangan dan perwujudan diri individu, terutama bagi pembangunan bangsa dan negara. Kemajuan suatu kebudayaan bergantung kepada cara kebudayaan tersebut mengenali, menghargai dan memanfaatkan sumber daya manusia dan hal yang berkaitan erat dengan kualitas pendidikan yang diberikan kepada seluruh masyarakat termasuk peserta didik. Tujuan pendidikan umumnya ialah menyediakan lingkungan yang memungkinkan peserta didik untuk mengembangkan bakat dan kemampuan secara optimal, sehingga ia dapat mewujudkan dirinya dan berfungsi sepenuhnya sesuai dengan kebutuhan masyarakat.

Berdasarkan deskripsi tersebut, peneliti tertarik untuk melaksanakan penelitian apakah penerepan kurikulum 2013 berpengaruh terhadap pembentukan karakter siswa, terutama siswa sekolah menengah pertama. Alasan peneliti melaksanakan penelitian ini pada siswa SMP karena siswa SMP dikategorikan pada proses belajar yang masih mudah untuk diberikan implementasi pendidikan karakter apabila hal ini sangat serius dilaksanakan oleh guru dalam proses belajar mengajar karena sebagaimana yang kita ketahui bahwa di dalam kurikulum 2013 Implementasi pendidikan karakter dilaksanakan pada saat proses belajar mengajar berlangsung. Penelitian ini akan dilaksanakan pada SMP Dwijendra alasan pemilihan sekolah ini berdasarkan observasi dan informasi yeng peneliti peroleh bahwa SMP Dwijendra Denpasar merupakan tempat peneliti melakukan PPL dan juga lembaga tersebut telah menerapkan kurikulum 2013.

\section{METODE}

Penelitian ini bersifat kualitatif. Penelitian di gunakan untuk mendapatkan sasaran data yang mendalam, suatu data yaang mengandung makna. Metode penelitian kualitatif adalah metode penelitian yang di gunakan untuk meneliti suatu obyek yang alamiah, (sebagai lawannya eksperimen) dimana peneliti sebagai instrumen kunci. 
Data primer adalah data yang di peroleh langsung dari lapangan. Data primer adalah data yang di kumpulkan atau di peroleh langsung di lapangan oleh orang yang melakukan penelitian atau yang bersangkutan. Sumber data primer di peroleh peneliti meelalui wawancara dengan responden. Responden dalam penelitian ini adalah kepalah sekolah, wakil kepala sekolah, kesiswaan, guru bimbingan konseling, dan siswa SMP Dwijendra Denpasar. Data sekunder adalah data yang di peroleh secara tidak langsung atau sumber lain yang ada, seperti buku - buku sebagai penunjang yang isinya berkaitan dengan topik penelitian. Dalam penelitian ini data sekunder di peroleh melalui buku - buku, artikel, jurnal, dan lain sebagainya yang berkaitan dengan topik penelitian.

Prosedur pengumpulan data merupakan kegiatan pencatatan peristiwa-peristiwa atau keterangan-keterangan maupun karakteristik sebagian atau keseluruhan elemen atau populsi yang akan mendukung penelitian Hasan (Dalam Ngurah, 2016:27). Untuk memperoleh data yang valid, obyektif dan variabel penulis menggunakan metode - metode sebagi berikut:

Penelitian ini menggunaakan alat pengumpulan data berupa pedoman atau instrumen wawancara yaitu berbentuk pertanyaan yang di ajukan pada subyek penelitian. Sedangkan wawancara yang di terapkan adalah wawancara instruktur. Wawancara instruktur, yaitu pedoman wawancara yang di susun secara terperinci sehingga menyerupai cheek-list.
Dokumen adalah catatan tertulis tentang berbagai kegiatan atau peristiwa pada waktu yang lalu. Yang penulis gunakan adalah dengan membaca literaur-literatur yang relevan, serta penggunaan dokumen-dokumen yang erat kaitannya dengan judul penelitian. Karena yang di teliti dalam penelitian ini adalah "Pengaruh Penerapan Kurikulum 2013 Terhadap Pembentukan Karakter SMP Dwijendra Denpasar" maka dokumen yang perlu di catat adalah segala hal yang berkaitan dengan topik tersebut.

Perpustakaan merupakan suatu tekik pengumpulan data yang dilakukan dengan membaca buku-buku, memahami dan mengutip isinya yang ada hubungannya dengan topik penelitian. Pemanfaatannya yaitu untuk menggali teori-teori dasar dan konsep yang telah di kemukakan oleh para ahli terdahulu, untuk memperoleh orientasi yang lebih luas mengenai judul penelitian.

Penelitian ini menggunakan metode analisis kualitatif deskriptif non statistik, dimana komponen reduksi data, dan sajian data di lakukan bersama dengan proses pengumpulan data dan setelah data terkumpul maka tiga komponen analisis (reduksi data, sajian data, penarikan kesimpulan) berinteraksi.

3. HASIL DAN PEMBAHASAN

Penerapan kurikulum 2013 terhadap pembentukan karakter siswa kelas VII H SMP Dwijendra Denpasar tahun pelajaran 2018/2019 
Pendidikan di Indonesia diharapkan dapat menciptakan manusia yang beriman dan bertakwa kepada Tuhan Yang Maha Esa, berakhlak mulia, sehat, berilmu, cakap, kreatif, mandiri, dan menjadi warga negara yang demokratis serta bertanggung jawab. Berdasarkan hal ini, jelas bahwa pendidikan di setiap jenjang harus diselenggarakan secara sistematis guna mencapai tujuan tersebut. Hal tersebut berkaitan dengan pembentukan karakter peserta didik yang mampu bersaing, beretika, bermoral, sopan, dan santun dalam berinteraksi dengan masyarakat. Kesuksesan seseorang tidak ditentukan sematamata oleh pengetahuan dan kemampuan teknis (hard skill) saja, tetapi lebih oleh kemampuan mengelola diri dan orang lain (soft skill). Hal ini mengisyaratkan bahwa mutu karakter peserta didik sangat penting untuk ditingkatkan.

Usaha untuk membentuk kedisiplinan bagi siswa memanglah diawali pada saat siswa berada pada lingkungan keluarga terutama orang tua yakni melalui proses sosialisasi norma-norma dan aturan-aturan dalam keluarga siswa itu sendiri. Selanjutnya ketika siswa masuk ke dalam lembaga pendidikan formal yakni sekolah, maka mulailah siswa diperkenalkan dan diajarkan sesuatu yang baru yang belum diajarkan dalam keluarga. Sekolah sebagai tempat sosialisasi kedua setelah keluarga, tempat anak dihadapkan kepada kebiasaan dan cara hidup bersama yang lebih luas lingkupnya serta ada kemungkinan berbeda dengan kebiasaan dan cara hidup dalam keluarganya, sehingga berperan besar dalam membentuk kedisiplinan pada diri siswa.
Disiplin akan terwujud melalui pembinaan sejak dini, sejak usia muda, dimulai dari lingkungan keluarga melalui pendidikan yang tertanam sejak usia muda yang semakin lama semakin menyatu dalam dirinya dengan bertambahnya usia, sehingga dalam hal ini, pendidikan khususnya di sekolah, disiplin harus bisa diterapkan kepada para siswa tentu saja dengan proses dan cara penerapan serta pembinaan yang berlanjut yang menjadikan siswa mempunyai kedisiplinan dalam dunia sekolah yang berlaku dalam dunia pendidikan. Dalam hal ini gurulah yang memiliki peranan penting dalam membentuk kedisiplinan siswa di sekolah.

Guru Pendidikan Kewarganegaraan memegang peranan yang sangat penting dalam pembentukan warga negara yang baik. Sebab guru Pendidikan Kewarganegaraan dituntut bukan hanya sebagai pemberi materi saja tetapi juga bertanggung jawab terhadap pembinaan watak dan karakter siswa. Pendidikan Kewarganegaraan merupakan salah satu mata pelajaran di sekolah yang memfokuskan pelajarannya pada pembentukan warga negara yang memahami dan mampu melaksanakan hak-hak dan kewajibannya untuk menjadi warga negara Indonesia yang cerdas, terampil, dan berkarakter diamanatkan oleh Pancasila dan UUD 1945. Adapun tujuan dari Pendidikan Kewarganegaraan yaitu membentuk karakter warga negara yang baik, yang salah satunya meliputi sikap disiplin siswa.

Kedisiplinan di SMP Dwijendra Denpasar sudah diperkenalkan kepada siswa semenjak siswa memasuki lingkungan sekolah 
ini, dimana siswa diperkenalkan dengan tata tertib sekolah dan sanksi poin. Kedisiplinan siswa di SMP Dwijendra Denpasar sudah berjalan dengan baik. Akan tetapi masih ada beberapa siswa yang tidak berdisiplin atau yang melanggar peraturan sekolah. Hal ini dikarenakan beberapa alasan, baik disengaja maupun tidak disengaja.

Dalam penelitian ini obsevasi pertama secara langsung dengan kepala sekolah, Guru PPkn dan siswa kelas VII H 05 juni 2019 pada saat proses belajar mengajar mata pelajaran Pendidikan Kewarganegaraan, mendapatkan siswa terlambat masuk ke dalam kelas (habis istirahat). Alasan kedua siswa tersebut terlambat masuk kelas karena pada saat istirahat, antri dalam membeli makanan. Selain itu, pada saat berlangsungnya pembelajaran, didapati siswa yang tertidur. Tindakan yang dilakukan guru Pendidikan Kewarganegaraan yaitu menegur dan menasehati siswa tersebut agar tidak mengulanginya kembali.

Selain itu, pada saat berlangsungnya pembelajaran, didapati siswa yang saling melempar kertas dengan siswa lain. Tindakan yang dilakukan guru Pendidikan Kewarganegaraan yaitu menegur dan menasehati siswa tersebut agar tidak mengulanginya kembali. Kasus atau pelanggaran yang paling nampak adalah mengenai siswa terlambat datang ke sekolah. Alasan siswa terlambat datang ke sekolah yaitu karena bangun kesiangan. Tindakan yang dilakukan oleh Guru Pendidikan Kewarganegaraan yaitu memberi sanksi membersikan wc guru dan siswa. Pelanggaran tersebut adalah terlambat datang ke sekolah, atribut tidak sesuai dengan ketentuan, tidak mengerjakan Pekerjaan Rumah, baju tidak dimasukkan, tidak masuk ke sekolah tanpa keterangan, menyontek, membolos, merusak fasilitas dan peralatan sekolah, tidak memakai sepatu, terlambat ikut upacara, terlambat masuk kelas setiap pergantian pelajaran, membuat kegaduhan di dalam kelas, berkelahi, tidak mengikuti upacara, tidak masuk ke sekolah dengan surat ijin yang dipalsukan, tidak mengikuti pelajaran di kelas, tidak memperhatikan pelajaran, membawa pisau, membawa handphone, dan membuang sampah sembarangan.

Setiap pelanggaran dari tata tertib tersebut, siswa akan dikenakan sanksi yaitu berupa peringatan lisan, peringatan tertulis, dan skors/poin sesuai dengan perhitungan dan waktu yang ditentukan. Anjuran untuk menaati tata tertib tersebut dilakukan oleh kepala sekolah berserta guru-guru lain pada saat upacara bendera, saat berlangsungnya proses belajar mengajar di kelas, ataupun pada saat di luar kelas atau di luar jam pelajaran.

Di lingkungan SMP Dwijendra Denpasar terus mengalami penurunan dalam berdisiplin yang berdampak pada prestasi belajar mereka. Menurunya kedisiplinan siswa ini disebabkan oleh berbagai faktor yakni faktor internal dan eksternal. Dalam berdisiplin banyak hal yang seharusnya menjadi contoh namun tidak berdisiplin sehingga para siswa juga mengikuti contoh tersebut. Adapun berbagai jenis 
pelanggaran yang sering dilakukan siswa di sekolah contohnnya terlambat datang sekolah bahkan sanksi yang sering di terimanya dari guru PPKn. Dari berbagai bentuk pelanggaran diatas maka Guru memiliki tugas dalam membentuk kerakter di dalam diri siswa sehingga para siswa akan terbiasa untuk menaati berbagai peraturan yang ada di sekolah maupun diluar sekolah.

Dari pernyataan kepala sekolah selaku guru PPKn dalam membentuk karakter siswa di SMP Dwijendra Denpasar di ketahui bahwa tindakan yang dilakukan guru pendidikan kewarganegaraan merupakan suatu upaya yang dilakukan untuk menumbuhkan sikap disiplin pada siswa yang mana diharapkan mampu dipahami, disadari dan diwujudkan dalam perilaku siswa.

Dari pembahasan di atas, dapat disimpulkan bahwa peranan guru Pendidikan Kewarganegaraan dalam membentuk kedisiplinan siswa di SMP Dwijendra Denpasar yaitu memberikan motivasi kepada siswa untuk lebih berdisiplin dengan cara menjelaskan kepada siswa akan manfaat dan keuntungan yang akan didapat jika siswa berdisiplin serta memberikan hukuman bagi siswa yang tidak berdisiplin atau yang melanggar peraturan sekolah dan memberikan hadiah kepada siswa yang berdisiplin atau yang tidak pernah melakukan pelanggaran; keteladanan dalam berperilaku dengan cara berperilaku dan bertutur kata yang sopan baik dengan sesama guru ataupun dengan siswa, memberi contoh berpakaian dengan rapi, hadir ke sekolah lebih awal dan tidak pulang lebih cepat dari siswa, dan masuk kelas tepat waktu; serta penyampaian materi yang berhubungan dengan kedisiplinan yaitu materi tentang norma yang berlaku di masyarakat, dimana dalam materi tersebut siswa diharapkan mampu menganalisis dan menerapkan norma baik agama, kesusilaan, kesopanan dan hukum, serta menekankan peraturan yang berlaku di sekolah.

Salah satu kendala guru-guru dalam membentuk karakter siswa di sekolah yaitu kendala dari faktor siswa. Terdapat beberapa siswa yang memang sulit untuk diajak berdisiplin atau memang yang dari bawaannya sulit diatur/bandel. Hal ini terlihat dari kebanyakan kasus pelanggaran yang pelakunya adalah siswasiswa itu saja. Banyak faktor yang menyebabkan siswa tersebut sulit untuk diatur yaitu faktor lingkungan pergaulan siswa yang kurang baik, dan juga faktor dari keluarga.

Kendala dari faktor guru yaitu kurangnya pengawasan dari guru Pendidikan Kewarganegaraan kepada siswa. Dilihat dari faktor guru bahwa kurangnya pengawasan dari guru Pendidikan Kewarganegaraan menyebabkan siswa banyak yang masih melakukan pelanggaran di sekolah. Kesibukan guru Pendidikan Kewarganegaraan dalam mengajar dan menjalankan tugasnya sebagai guru, sehingga mengakibatkan kurangnya guru tersebut dalam mengawasi kedisiplinan siswa di sekolah.

Guru Pendidikan Kewarganegaraan perlu melakukan pendekatan kepada siswa yang sering melanggar peraturan sekolah atau yang sering tidak berdisiplin di sekolah. Hal ini perlu dilakukan 
untuk mengetahui penyebab siswa tersebut sering melanggar peraturan sekolah atau tidak berdisiplin di sekolah. Penyebab siswa tersebut melanggar peraturan sekolah atau tidak berdisiplin di sekolah berasal dari faktor lingkungan pergaulan atau berasal faktor dari keluarga.

Selain itu, guru Pendidikan Kewarganegaraan perlu menanamkan kesadaran kepada siswa akan pentingnya berdisiplin. Dalam hal ini, guru Pendidikan Kewarganegaraan perlu melakukan pembinaan dengan menanamkan nilainilai kepada siswa akan pentingnya kesadaran menaati peraturan sekolah atau berdisiplin. Siswa diberikan pembinaan untuk senantiasa memiliki perilaku yang tertib dan patuh terhadap peraturan di sekolah. Pembinaan ini dilakukan guru Pendidikan Kewarganegaraan pada setiap pertemuan di kelas maupun pada saat berkesempatan menjadi pembina upacara bendera yaitu menyisipkan himbauanhimbauan untuk berdisiplin atau mematuhi peraturan sekolah. Pembinaan ini bertujuan agar siswa sadar akan pentingnya berdisiplin.

Selain itu juga, diperlukan kerjasama yang baik antara pihak sekolah dengan orang tua siswa dalam membentuk kedisiplinan siswa. Dalam membentuk kedisiplinan siswa tidak hanya menjadi tanggung jawab guru, tetapi juga tanggung jawab orang tua atau keluarga. Keluarga atau orang tua merupakan pendidik pertama dan utama yang sangat besar pengaruhnya dalam pembinaan dan mengembangan perilaku siswa. Kerjasama orang tua dengan guru sangat penting bagi peningkatan kedisiplinan siswa, baik kedisiplinan siswa di rumah maupun kedisiplinan siswa di sekolah. Kerjasama antara guru dengan orang tua haruslah dibina secara intensif dan proaktif yaitu kerjasama guru dengan orang tua siswa dalam mengontrol perilaku siswa, memanggil orang tua siswa apabila siswa melakukan pelanggaran di sekolah, dan mengundang orang tua siswa apabila mengadakan rapat di sekolah untuk memecahkan masalahmasalah dalam mengembangkan pribadi peserta didik.

\section{PENUTUP}

Memberikan motivasi kepada siswa untuk lebih berdisiplin, yaitu dengan menjelaskan kepada siswa akan manfaat dan keuntungan yang akan didapat jika siswa berdisiplin, memberikan hukuman bagi siswa yang tidak berdisiplin atau yang melanggar peraturan sekolah, dan memberikan hadiah kepada siswa yang berdisiplin atau yang tidak pernah melanggar peraturan sekolah. Keteladanan dalam berperilaku, yaitu dengan berperilaku dan bertutur kata yang sopan baik dengan sesama guru ataupun dengan siswa, memberi contoh berpakaian dengan rapi, hadir ke sekolah lebih awal dan tidak pulang lebih cepat dari siswa, dan masuk kelas tepat waktu. Penyampaian materi yang berhubungan dengan kedisiplinan yaitu materi tentang norma yang berlaku di masyarakat. Dalam materi tersebut siswa diharapkan mampu menganalisis dan menerapkan norma yang berlaku di masyarakat, baik norma agama, kesusilaan, kesopanan dan hukum, serta menekankan peraturan yang berlaku di sekolah. 
Hambatan-hambatan yang dihadapi Kepala sekolah dalam membentuk kedisiplinan siswa serta upaya untuk mengatasi hambatan tersebut di SMP Dwijendra Denpasar Tahun Pelajaran 2018/2019: Hambatan dari faktor siswa, yaitu terdapat beberapa siswa yang memang sulit untuk diajak berdisiplin atau memang yang dari bawaannya sulit diatur/bandel. Hal ini terlihat dari kebanyakan kasus pelanggaran yang pelakunya adalah siswasiswa itu saja. Banyak faktor yang menyebabkan siswa tersebut sulit untuk diatur yaitu faktor lingkungan pergaulan siswa yang kurang baik, dan juga faktor dari keluarga siswa. Kesibukan orang tua mengakibatkan siswa tersebut kurang mendapat perhatian dari kedua orang tuanya. Hal ini sangat berpengaruh negatif bagi perkembangan perilaku siswa. Kendala dari faktor guru, yaitu kurangnya pengawasan dari guru Pendidikan Kewarganegaraan menyebabkan siswa banyak yang masih melakukan pelanggaran di sekolah. Kesibukan guru Pendidikan Kewarganegaraan dalam mengajar dan menjalankan tugasnya sebagai guru, sehingga mengakibatkan kurangnya guru tersebut dalam mengawasi kedisiplinan siswa di sekolah.

Upaya yang dilakukan guru-guru untuk mengatasi kendala-kendala dalam membentuk karakter siswa di SMP Dwijendra Denpasar: Upaya untuk mengatasi kendala dari faktor siswa, yaitu dengan melakukan pendekatan kepada siswa, menanamkan kesadaran kepada siswa akan pentingnya berdisiplin, dan membangun kerjasama yang baik antara pihak sekolah dengan orang tua siswa dalam membentuk kedisiplinan siswa.
Upaya untuk mengatasi kendala dari faktor guru yaitu dengan bekerjasama dengan guru-guru lain, wali kelas, dan ketua-ketua kelas dalam membentuk kedisiplinan siswa di sekolah.

\section{DAFTAR PUSTAKA}

Arikunto, Suharsimi. 2002. Prosedur Penelitian Suatu Pendekatan Praktek, Cetakan Kedua Belas (Edisi Revisi V). Jakarta: PT. Rineka Cipta.

Darwati, Mas \& Mahendra, Putu Ronny Angga. 2019. Efektivitas Pembelajaran PPKn Berbasis Teknohumanistik Dalam Pembentukan Karakter Siswa Kelas X Jasa Boga 2 di SMK Prshanti Nilayam Kuta Tahun Pelajaran 2017/2018. Singaraja: FHIS Universitas Pendidikan Ganesha.

Husnaini, A. (2010). Pengertian KarakterAmri, S. 2013. Pengembangan \& Model Pembelajaran dalam Kurikulum 2013. PT Prestasi Pustakaraya. Jakarta.

Kemendikbud. 2013. Kerangka Dasar Kurikulum 2013. Kementerian Pendidikan dan Kebudayaan Direktorat Jenderal Pendidikan Dasar. Jakarta

Komalasari, kokom, 2011 Pendidikan Karakter. Bandung. PT. Refika aditama.

Mahendra, Putu Ronny Angga. Pembelajaran PPKn Dalam Resonansi Kebangsaan dan Globalisasi. Jurnal Ilmiah Ilmu Sosial. Singaraja : Universitas Pendidikan Ganesha.

Mulyasa, E. Manajemen Pendidikan Karakter. Jakarta: Bumi Aksara, 2012.

Sugiyono. (2016). Metode Penelitian Kuantitatif Kualitatif dan $R \& D$. Bandung: Alfabeta

Undang-undang No. 20 Tahun 2003, Tentang Sistem Pendidikan Nasional. Dirjen Dikti Depdiknas. Jakarta.

Wibowo, Agus. (2012). Pendidikan Karakter: Strategi Membangun Bangsa 
Berparadigma. Yogyakarta: Pustaka Pelajar.

Winaya, Astra,2017. “Efektivitas Pengembangan Nilai-nilai Karakter Pada Peserta Pesraman Kilat Tingkat Dasar di Desa Pekraman Selan Bawak,Keamatan
Marga,Kabupaten Tabanan-Bali. ’Jurnal Widya Accarya.Fakultas Keguruan dan Ilmu Pendidikan Universitas Dwijendra, E-Jurnal.ac.id., Denpasar. 